\title{
Liposomal Amphotericin B
}

National Cancer Institute

\section{Source}

National Cancer Institute. Liposomal Amphotericin B. NCI Thesaurus. Code C1566.

A liposome-encapsulated formulation of the polyene antifung al antibiotic amphotericin $B$ produced by the bacterium Streptomyces nodosus with antifung al activity. Amphotericin $B$ binds to ergosterol, an essential component of the fungal cell membrane, and alters cell membrane integ rity, resulting in leakage of intracellular components and cell rupture. This agent may also induce oxidative damage in fungal cells and has been reported to stimulate host immune cells. Compared to amphotericin B alone, liposomal delivery of amphotericin B allows for a greater drug concentration in target tissues while decreasing systemic side effects. 